\title{
Attitude of Hungarian companies towards challenges created by EU-accession"
}

\author{
Károly Balaton ${ }^{* *}$
}

The paper analyses expectations and company strategies in relation to Hungary's joining the European Union. Data was collected from mainly medium-sized Hungarian companies by a questionnaire survey between January and April 2004. Companies perceived high level of uncertainty in relation to joining the EU. Many companies regard the accession as a possibility for expanding their business. Most of the respondents shared the view that after joining the Union competition would be increased and additional measures would be necessary to keep highly qualified work force. Preparing for the period after the accession can not be regarded as a primary strategic goal for the responding companies. This is partially explained by the fact that the sample includes companies mainly oriented toward the domestic market.

Der Aufsatz analysiert Erwartungen und Unternehmensstrategien in Relation zum EU-Beitritt. Daten wurden von hauptsächlich mittelgroßen ungarischen Unternehmen anhand einer Umfrage zwischen Januar und April 2004 erhoben. Unternehmen empfanden große Unsicherheit bezüglich dem EU-Beitritt. Viele Firmen sahen den Beitritt als eine Möglichkeit zur Geschäftserweiterung an. Die meisten Befragten teilten die Ansicht, dass nach einem Beitritt der Wettbewerb sich verstärken würde und dass weitere Maßnahmen nötig wären, um hochqualifizierte Arbeitskräfte zu erhalten. Die Vorbereitung auf die Zeit nach dem Beitritt ist keine primäres strategisches Ziel. Dies wird teilweise dadurch erklärt, dass von der Umfrage auch Unternehmen erfasst worden sind, die sich auf den auf den einheimischen Markt konzentrieren.

Keywords: European Union / Hungary / competition / survey / domestic market

\footnotetext{
Manuscript received: 26.08.05, accepted: 01.09 .05 (no revision)

** Károly Balaton, Professor, Siemens Chair of Management at the Corvinus University of Budapest. Main research areas: Strategic management, organizational change in transforming societies, influence of EU-accession on company management. Corresponding address: karoly.balaton@uni-corvinus.hu
} 


\section{Introduction}

The Hungarian economy - like many other economies in Central and Eastern European countries - has gone through systemic transformation during the 1990s. The economic transformation, parallel to radical changes in the political and social systems, resulted in conditions similar to market economies in Western European countries (Temesi/Zalai 1999). Companies have developed capabilities enabling them to compete with firms situated in developed market economies (Chikán/Czakó/Zoltay-Paprika 2002). At the beginning of the twenty-first century the transformed economies and enterprises within them have been faced with a new challenge, i.e. joining the European Union.

For the Hungarian economy and its companies it is a decisive question what conditions will be existing after joining the European Union, and to what extent they will be capable of adapting to the new situation. The Competitiveness Research Centre within the Corvinus University of Budapest has conducted a survey from January to April 2004 involving three hundred companies respondig to the questionnaires. Part of the survey was related to studying opinions of enterprise managers on possible consequences of the integration, and on measures they have taken to prepare for the new conditions. The centre conducted similar surveys in 1996 and 1999. One of the aims of the recent study was to compare the findings with results of the previous studies. The present paper builds on the publication of the "Gyorsjelentés" (Fast Report) (Chikán/Czakó/Zoltay-Paprika 2004) and on other unpublished results of the analysis.

\section{Characteristics of the "Competitiveness" survey}

The sample included 301 companies responding to the questionnaire (response rate was 23 per cent). Respondents were mainly representing medium-sized manufacturing companies oriented towards the domestic market (50 per cent). Distribution of other branches was as follows: services -12 per cent, trade -10 per cent, extraction and energy services -7 per cent, construction -6 per cent, public services -5 per cent, agricultural production -3 per cent.

The questionnaire consisted of four parts, namely to be responded by CEOs, marketing, production and financial managers.

Companies in the sample were mainly employing more than 50 persons. Companies with less than 50 employees represented only 5 per cent of the sample. The composition of the sample according to number of employees was as follows: between 51 and 99: 28 per cent; between 100 and 299: 35 per cent; between 300 and 499: 11 per cent; between 500 and 999: 10 per cent; above 1000: 11 per cent.

After analysing data collected by the questionnaires, the research work will be continued by qualitative methods. First, interviews with company top managers 
will be conducted in September and October 2005. The rest of the year 2005 will be devoted to collecting information for developing case studies of selected companies belonging to the sample. Parallel to writing case studies, round-table discussions will be organized with managers of firms operating in Hungary. The methodological approach choosed by the research designers (Chikán/Czakó/Paprika, 2005) is that of triangulation favouring both quantitative as well as qualitative approaches (Jick 1979; Van Maanen 1979) to understand the complex isssues of competitiveness of Hungarian enterprises in the period of joining the European Union. Further research evidence will be available and published in different journals by the end of 2006 .

In the following part we present the first results of the survey related to attitudes and expectations of Hungarian company managers concerning the consequences of joining the European Union.

\section{Company managers' opinion on possible consequences of joining the European Union ${ }^{1}$}

Here we shall analyse responses to the following questions:

- What level of uncertainty was perceived by the company three to four years ago and recently?

- How did they evaluate changes connected to the EU-accession from the point of view of successful company activities?

- What will the consequences of EU-accession be for the financial and marketing capabilities of the company?

\section{Perceived level of uncertainty by managers}

Company managers perceived increased uncertainty in the environment of their company compared to the situation three-to-four years before. The major sources of uncertainty were the home market, the legal regulations and changes connected to joining the EU. It is noteworthy that perceived uncertainty due to EU-accession was larger during the period of the survey than three or four years before (see Table 1). Domestic and foreign suppliers, technological development, political as well as social changes in the country were regarded as relatively stable environmental segments.

${ }^{1}$ Contributions made by the following researchers are acknowledged: Zoltán Buzády, Lilla Hortoványi, Emma Incze and Krisztina Tóth. 
Table 1. Perceived level of uncertainty related to EU-accession in 2000-2001 and in 2004.

\begin{tabular}{|l|c|c|c|c|}
\hline $\begin{array}{l}\text { Perceived } \\
\text { uncertainty }\end{array}$ & $\begin{array}{c}\text { No. of } \\
\text { companies 3-4 } \\
\text { years before }\end{array}$ & $\begin{array}{c}\text { \% of } \\
\text { companies 3-4 } \\
\text { years before. }\end{array}$ & $\begin{array}{c}\text { No. of } \\
\text { companies in } \\
\mathbf{2 0 0 4}\end{array}$ & $\begin{array}{c}\text { \% of companies in } \\
\mathbf{2 0 0 4}\end{array}$ \\
\hline $\begin{array}{l}\text { No } \\
\text { uncertainty }\end{array}$ & 77 & 28.1 & 28 & 10.1 \\
\hline $\begin{array}{l}\text { Limited level } \\
\text { of uncertainty }\end{array}$ & 76 & 27.6 & 51 & 18.4 \\
\hline $\begin{array}{l}\text { Medium level } \\
\text { uncertainty }\end{array}$ & 78 & 28.5 & 69 & 24.9 \\
\hline $\begin{array}{l}\text { High level } \\
\text { uncertainty }\end{array}$ & 31 & 11.3 & 86 & 15.5 \\
\hline $\begin{array}{l}\text { Extremely } \\
\text { high level } \\
\text { uncertainty }\end{array}$ & 12 & 4.4 & 43 & \\
\hline Total: & 274 & 100.0 & 277 & 100.0 \\
\hline
\end{tabular}

Compared with the survey results of 1999 , perceived uncertainty due to technological development and political changes within the country was at a lower rate. Compared to the findings of the 1996 survey, uncertainty connected to domestic sales market and financial market became much lower. Social changes contributed to the lower level of uncertainty between 1996 and 1999, but it has increased since 1999, now reaching a level similar to that of 1996. Foreign suppliers were regarded as the most stable environmental segment in each survey. In the surveys conducted in 1996 and 1999 we raised questions related to foreign and regional changes. In the 2004 survey we replaced this question with changes due to the EU-accession. Perceived uncertainty related to these questions was at the lowest level in 1999. We observed an increase in this measure between 1996 and 1999, and after 1999 as well. Further inquires will be necessary to identify the reasons why company managers perceived increased uncertainty parallel to coming closer to the accession. As negotiations on conditions of accession progressed, more and more information has been available on possible conditions of the EU-enlargement. One would expect the uncertainty decreases in this period, but our respondents expressed different opinions.

A smooth relationship with customers was the environmental factor which had the most influence on enterprise activity. 84.8 per cent of the respondents regarded it to be the most relevant factor, which is 8 per cent higher than the figure in 1999. The second most important element of the environment was a good relationship with suppliers (according to 61.9 per cent of the managers). Domestic and foreign competition was evaluated as relatively less influential. Less than half of the companies believed this factor to be an important environmental segment. Government level economic policy was named as 
important by 35.2 per cent of the responses, EU-accession by 34.1 per cent. Purchasing market and technological development was rated as the least influential element of company environment.

Ranking of environmental elements according to their relevance for the company was rather similar to findings in 1996 and 1999. Domestic market was seen as more important than foreign competition in all surveys. Behind these responses we may identify a domestically oriented company behaviour, which is supported by the fact that a relatively low percentage of the respondents regarded EU-accession as a factor of high relevance. Comparing this finding with the opinion that firms perceived increased uncertainty parallel to getting closer to the date of accession, we may identify company behaviour tending to avoid uncertainty and concentrating on the domestic market which was perceived as more certain.

Regarding customer relationships as the first priority of management is similar to findings in developed market economies. However, regarding domestic and foreign competition as a less relevant environmental factor is contradictory to the findings of Western economies (Hofmeister-Tóth 2003).

The most hindering environmental elements were national economic policy (51.8 per cent of respondents), domestic economic situation ( 49.5 per cent) and functioning of the Government ( 40.5 per cent). We have to mention that in the survey of 1999 the same factors were mentioned as most hindering. Changes related to EU-accession, connections to ministry, domestic and foreign economic situation were named as mostly supportive elements of the environment. The survey results show that companies have diverse opinions on the domestic economic situation. This statement is supported by the fact that 29.4 per cent of respondents regarded it as a neutral factor. Changes connected to EU-enlargement were seen as supportive environmental factor. This condition is contradictory to the findings that EU-accession was evaluated as a factor resulting in increasing uncertainty, and that relatively small percentage of the companies regarded it as an element having high relevance. National economic policy, domestic economic situation and functioning of the Government were mentioned as the most hindering factors in the survey of 1996 as well. We may argue that company managers are steadily dissatisfied with the operation of the Hungarian Government.

\section{Company executives' evaluation of changes connected to the EU- accession and from the point of view of successful company activity}

Several of the questions were raised for both general managers and financial managers. According to the answers given by general managers opinions forecasting positive consequences for the company have a narrow majority. The 
answers show strong diversity. Nearly 40 per cent of the respondents regarded the consequences of EU-enlargement as neutral. Positive consequences were forecasted by 33.4 per cent, and negative outcomes by 22.1 per cent.

\section{Influence of EU-accession on financial and marketing capabilities of companies - questions answered by both general and financial managers}

The survey included the following questions:

- Will the costs of entry to foreign markets be decreased?

- Will economic connections with companies of non-EU countries be decreased?

- Will the company receive relevant support from the EU?

- Will the EU-support have unfavourable consequences for the competitiveness of enterprises?

The above questions were answered by using a scale with five elements:

1. fully disagree,

2. mostly disagree,

3. neutral,

4. mostly agree,

5. fully agree.

Will the costs of entry to foreign markets be decreased?

Our data show basic similarities between the opinion of general managers and financial managers, as they formed opinion on the same issue. However, contrasting views might also be possible because perception of complex issues may be different by individuals, so even large differences can be explained.

Neutral answers had a larger frequency among financial managers (39.5 per cent), compared with 35.0 per cent of general managers. Summing up the frequencies of mostly and fully agreeing answers the results were rather similar. General managers expressed disagreement more frequently ( 34.5 per cent) than financial managers (30.6 per cent).

Will economic connections with companies of non-EU countries be decreased?

Differences between the opinion of the two groups of managers were significant for this question. 59.8 per cent of general managers expressed disagreement (fully disagree and mostly disagree), while in case of financial managers this figure was 51.0 per cent. Neutral opinions were formed by financial managers more frequently. The frequency of agreement (mostly agree and fully agree together) was similar to the latter point(10.1 versus 11.8 per cent). 
Will the company receive relevant support from the EU?

Looking at the data we may observe that financial managers were more optimistic than general managers concerning the possibilities of getting support from the EU. 34.5 per cent of the first expressed agreement, while the ratio of the latter was 29.4 per cent. Neutral answers were more frequent among financial managers (34.3 versus 27.1 per cent). Non-agreement was more characteristic for general managers (43.5 versus 31.2 per cent).

\section{Consequences of EU-support for the competitiveness of enterprises}

The question was formed in the following way: Will the EU-support have unfavourable consequences for the competitiveness of enterprises?

Relatively small differences were observable between the opinions of general and financial managers. General managers expressed full disagreement more frequently (41.7 per cent) than financial managers ( 29.0 per cent). If we take into account partial disagreement as well, then the difference will be less observable. Frequencies of the mostly disagreeing and fully disagreeing answers are similar in both groups of managers. We may conclude that company managers do not count on unfavourable consequences for competitiveness due to support from EU.

\section{Influence of EU-accession on financial and marketing capabilities of companies - questions answered by general managers only}

Possible answers to the question were formed as following:

- Possibilities for sales will significantly increase by the EU-accession;

- Our company will be faced with stronger competitors;

- Export will be more important and will increase;

- The Market position of our company will not change significantly;

- We may count on a broader supplier base with an improved quality of goods;

- Our major competitors will be the companies from the joining countries;

- Cooperation with other companies will have a more significant role;

- We can hire cheaper and more qualified labour force;

- Significant measures will be necessary to keep highly qualified employees;

- Countries that joined the EU recently will provide relevant market for our company;

- Countries of the EU-15 will provide relevant market for our company;

The same scale as above was used for these items. 
Will our possibilities for sales significantly increas by the EU-accession? Looking at the results we may state that the opinions of company managers showed significant diversity concerning the possibilities for sales. Disagreeing answers were the most frequent (42.3 per cent), but neutral responses were also held (32.4 per cent). Agreement (partial and full together) was expressed by 25.3 per cent of the responding managers.

Will our company be faced with stronger competitors?

Data show that companies count on increased competition. 56.2 per cent expressed agreement, while the ratio of disagreement was only 20.8 per cent.

Will export be more important and increase?

We may state that companies do not count on relevant increase in their export activity. 44.5 per cent expressed disagreement, 34.1 per cent were neutral and only 21.4 per cent of general managers agreed.

Will the market position of the company change significantly?

More than one third of the companies gave a neutral answer to this question. 43.2 per cent expected unchanged market position, and only 21.1 per cent forecasted changes.

May we count on a broader supplier base with an improved quality of goods?

41.8 per cent of respondents expressed a neutral opinion. Total and partial disagreement together was shared by 31.1 per cent. Partial and full agreement was the opinion of 26.2 per cent of top managers. We may conclude that opinions rather differ in this question.

Will our major competitors be companies from the joining countries?

Our data show that most of the companies do not count on companies from the joining countries as their major competitors. 42.9 per cent of respondents disagreed and 30.5 per cent expressed agreement.

Will cooperation with other companies have a more significant role?

Answers to this question show strong diversity of opinions. 34.9 per cent gave a neutral answer. The frequency of agreement ( 37.4 per cent) is the same as the ratio of disagreement (37.7 per cent).

Can we hire cheaper and more qualified labour force?

Our respondents gave mainly negative answers to this question. 81.1 per cent expressed full or partial disagreement, while only 2.5 per cent gave positive answers. 16.4 per cent had a neutral opinion. 
Will significant measures be necessary to keep highly qualified employees?

About half of the companies (50.6 per cent) expressed agreement with the necessity of significant measures. Frequency of disagreement was 23.1 per cent. We may conclude that a majority of top managers felt the necessity to take measures to keep qualified employees.

Will the countries that joined the EU recently provide relevant market for the company?

Data show that the majority of companies do not count on relevant market opportunities in joining countries. 52.7 per cent expressed disagreement and only 10.9 per cent gave a positive answer.

Will the countries of EU-15 provide relevant market for the company?

More than a half of the responding managers (53.7 per cent) did not count on increased market opportunities in EU-15. Enlarged market possibility was forecasted by 21.7 per cent of the top managers.

\section{Enterprise strategies in relation to EU-accession}

The most important strategic goal of enterprises is to meet the expectations of their customers as much as possible. Profit maximization took the second place among the strategic priorities. 92 per cent of the companies gave the answer that meeting customer expectations has first priority. In the survey of 1999 this ratio was 88.2 per cent, so we may recognize an increasing customer orientation in the sample. Profit maximization was named as the most important priority. 64 per cent of the companies regarded profit to be an outstanding strategic goal. It is noteworthy that 14 per cent of the company did not regard profit as crucially important. The importance of profit has decreased compared to the findings in 1999. In the survey in 199686.9 per cent shared the opinion that meeting customer expectations has major strategic priority. In that survey profit maximization was mentioned by 68.6 per cent as outstanding prime concern. Customer satisfaction has become more and more important, while the importance of profit has been slowly decreasing. Putting customer at the first place is a tendency observable in developed market economies as well (see Wind/Main 1998).

The most frequent way of adaptation to environmental changes is recognition of changes in time and pre-active response, which is characteristic for 37.3 per cent of companies in our sample. Nearly the same percentage of companies declared to recognize the changes and to react to these. 11.6 per cent responded in the way that they forecasted the changes and tried to influence the direction of changes. Ratio of companies which recognize changes but incapable to give adequate answer was 11.2 per cent. Only 2.9 per cent were incapable of 
recognizing changes in time. These answers show high level adaptation capabilities of enterprises. Almost a half of the firms (48.9 per cent) was capable to forecast possible changes. 48.2 per cent recognized the alterations and most of these enterprises were capable of giving reactions to them.

Adaptation to environmental changes is similar to our survey result from 1996 and 1999. Differences in frequencies of specific answers are not significant. The picture from 1999 is slightly more positive because the ratio of companies forecasting changes and giving proactive response was the highest (41 per cent), and ratio of companies which recognized changes but were incapable to give answer was the lowest ( 9 per cent). Our surveys show that companies located in Hungary have successfully developed their adaptation capabilities after the changes in the system. Their operations have been similar to that of firms in developed market economies.

Company strategies have gone through relevant changes between 2000 and 2003. In 2000 the most frequently used strategy was shrinking (32.6 per cent). One year later the ratio of companies having shrinking strategy was only 8.7 per cent. At the same time the use of focus strategies was 25.7 per cent, and companies with stabilisation strategies represented 20.2 per cent of our sample. In 2002 the defensive strategy was the most frequently used one ( 23.8 per cent), followed by growth oriented strategies ( 22.5 per cent). In 2003 an increased use of offensive strategies was observable (45.2 per cent), while its frequency was only 9.7 per cent in 2000. Lack of clearly defined strategy was mainly reported for 2001.

Typology of possible strategies was extended in the 2004 survey by the focused strategy, where a company concentrates its operation on a relatively narrow product-market segment. Our data show that this type of strategy was mainly used in 2001, when neither growth nor shrinking strategies were characteristic for companies in our sample. The answers show that before changing from a passive to an active strategy, companies tried to stabilize their position and concentrated on a narrower product-market segment.

We also measured internationalization of companies by their exports and foreign direct investments. Only 10.4 per cent of companies had foreign direct investment. This fact shows that Hungarian owned medium-sized enterprises, being characteristic for our sample, concentrate on the domestic market and are at a low level of internationalization. Foreign direct investment was mainly motivated by foreign market expansion strategies ( 75 per cent). The second most important factor was growth having strategic significance and preserving long term competitive position, which was characteristic for 56.3 per cent of the respondents. Getting access to resources was relatively less important, only 31.3 per cent regarded it as relevant. Improved efficiency of operations motivated only 12.5 per cent of firms toward FDI. This circumstance may be connected to 
the fact that companies were rather too small to be able to realize economies of scale and scope through geographical diversification.

\section{Changes in company strategies due to the coming EU-accession}

Our survey shows that half of the companies (49.6 per cent) retained their strategies, 41.5 per cent introduced moderate changes, and only 8.9 per cent of firms made basic changes. We may argue that company managers probably underestimated the consequences of EU-accession and their strategic preparation was only moderate.

How did companies prepare for the period after the EU-enlargement?

Only 120 companies answered this question. The limited number of response is due to the structure of our questionnaire: only those companies answered the question which used formalized strategic planning systems. The answers show strong diversity. 35.8 per cent of firms started preparation years before the accession. 30.8 per cent started to prepare in the previous year. 33.5 per cent shared the opinion that the EU-accession will not result in changes that need strategic preparation. That kind of response is probably connected to our previous finding that many of the firms in our sample had mainly domestic market orientation and internationalization were not part of their strategic considerations.

\section{Summary}

Our survey shows that companies perceived a high level of uncertainty concerning the possible consequences of EU-accession. The level of perceived uncertainty was higher than three or four years before. Uncertainty of opinion is also reflected by the diversity of opinions among top managers. We observed differences in opinions expressed by general managers and financial managers as well. Financial managers were more optimistic regarding the possibility of getting financial support from EU.

At the same time companies had high expectations for the period after joining the EU. These expectations were mainly positive, although contradictions may be observed in perceptions. Opinions were diverse concerning the possibilities for expanding sales. Company managers mainly were pessimistic about an increasing demand for their products and services. The majority of respondents counted on increased competition and difficulties in maintaining highly skilled labour force.

Preparation for conditions after the EU-accession may not be regarded as a strategic aim having priority among the remonding companies. This finding is probably connected to the fact that companies in our sample were mainly 
oriented towards the domestic market, their expansion on foreign markets was rather limited.

Company strategies mainly favoured to meet customer expectations. Profit maximization was a goal having lower priority compared to customer orientation. Responding managers expressed relatively high level adaptation capabilities to environmental changes. Preactive adaptation was reported as the most frequent way of reaction to changes.

Type of company strategies went through relevant changes at the beginning of the new century. In the first years thrinking and stabilization strategies were mainly used. It was changed to defensive strategies in year 2002 followed by offensive and growth oriented strategies in 2003. The content of enterprise strategies showed stronger connection to international economic trends than to initiatives of the Hungarian Government.

\section{References:}

Chikán, A./Czakó, E./Zoltay-Paprika, Z. (2002): National Competitiveness in Global Economy: The Case of Hungary. Budapest: Aula Publishing House.

Chikán, A./Czakó, E./Zoltay-Paprika, Z. (2004): Fókuszban a verseny. Gyorsjelentés a 2004. évi kérdőíves felmérés eredményeirool. (Competition in the Focus. Fast report on results of the survey in 2004.) Budapest: Corvinus University of Budapest, Competitiveness Research Centre.

Hofmeister-Tóth, Á. (2003): Fogyasztói magatartás (Customer behaviour) Budapest: Aula Publishing House.

Jick, T.D. (1979): Mixing Qualitative and Quantitative Methods: Triangulation in Action. Administrative Science Quarterly, vol. 24. no. 4., 602-611.

Temesi, J./Zalai, E. (1999): Back to a Market Economy. Budapest: Akadémiai Kiadó (Academic Publishing House).

Van Maanen,J. (1979). Reclaiming Qualitative Methods for Organizational Research. Administrative Science Quarterly, vol. 24., no. 4.

Wind, J.Y./Main, J. (1998): Driving Change. New York: The Free Press. 